\title{
Is A Gender Analysis of Social Policy Still Required in High Income Countries? A Case Study of The New Zealand Sole Parent Benefit; Objectives and Outcomes
}

Katheryn Margaret Pascoe

Institute of Development Studies, Sussex University

\section{ARTICLE INFO}

\section{Keywords:}

Social Welfare

Gender Analysis

Feminist Economics

New Zealand

\begin{abstract}
New Zealand is considered an egalitarian society, with a progressive policy history in promoting gender equality, however, this paper illustrates how social policy does not always support this agenda. The objective of New Zealand Sole Parent Benefit is to provide temporal financial support to sole parents and their dependents while supporting a transition into formal paid employment. While ultimately aimed at increasing the labour force participation of sole parents, this paper queries to what extent the policy has achieved this objective and why. Recipient statistics are disaggregated by gender to highlight the disproportionate impact on, and unequal outcomes for women. Furthermore, a gendered analysis informed by feminist economists Naileer Kabeer, Diane Elson and Nancy Folbre, alongside statistical evidence of a gender pay gap, occupational segregation and motherhood penalty is applied to demonstrate how market constraints affect New Zealand women's participation in the labour force, and contribute to the counter intuitive policy results. While these factors do not account for individual differences in motivation, nor individual aspirations, unless the gendered nature of the labour market is addressed, women will continue to face higher rates of engagement on the Sole Parent Benefit and continue to experience disproportionate economic disadvantage and financial insecurity. The consistent use of a gendered analysis in policy design and implementation is essential to reduce gender-based disadvantage, even in countries believed to promote gender equality.
\end{abstract}

\section{Introduction}

The New Zealand Sole Parent Benefit provides temporal financial support to sole parents and their dependents while supporting parents to transition into formal paid employment, aimed at increasing the labour force participation of recipients (Social Security Act, 1964). This paper will query to what extent the policy has achieved this objective and why, through descriptive statistics and the application of a gender analysis.

New Zealand is considered an egalitarian society, with a progressive policy history in promoting gender equality. It is ranked 16th out of 189 on the United Nations Gender Inequality index (United Nations Development Program, 2018). As a multi-factorial measure, this index takes into account gendered gaps in educational attainment, labour force participation and political representation, alongside maternal mortality rates and adolescent birth rates (United Nations Development Program, 2018). New Zealand was also the first country to grant all women the right to vote in 1896 , and the first country to establish paid employment leave for domestic violence victims (Domestic Violence-Victims' Protection Act, 2018). However,

* Corresponding Author E-Mail Address: pascoe-km@ulster.ac.uk 
despite New Zealand being a pioneer for establishing gender rights, this case study illustrates all policies do not necessarily promote gender parity.

After outlining the policy objectives, obligations, penalties and incentives, this paper will provide a statistical overview of recipients disaggregated by gender to highlight the disproportionate impact on, and unequal outcomes for women. A gendered analysis, informed by feminist economists Naileer Kabeer, Diane Elson and Nancy Folbre, will assess how market constraints affect New Zealand women's participation in the labour force, and contribute to the counter intuitive policy results. Ultimately, the Sole Parent Benefit fails to recognise or address how labour markets operate as gendered institutions, one of the key contributing factors to the unequal policy outcomes, and is a missed opportunity for enhancing gender equality. Furthermore, this paper advocates for the consistent use of a gendered analysis in policy design and implementation to reduce gender-based disadvantage (Cagatay, Elson \& Grown, 1995; Cameron \& Gibson-Graham, 2003).

\section{Background: Sole Parent Benefit in New Zealand}

Through an amendment to the Social Security Act (1964), the New Zealand Sole Parent Benefit was established in 2012 and is administered through the Ministry of Social Welfare. The Social Security Act also sets parameters for additional supplementary benefits, with different eligibility criteria; however, the Sole Parent Benefit is the only one that caters specifically to single parents and their dependents. An overview of the complete social welfare system in New Zealand is beyond the capacity of this paper.

\subsection{Policy objectives, obligations and penalties.}

The key objective of the Sole Parent Benefit is to transition sole parents in paid labour force participation. Through the use of obligations, this policy is an example of the State harnessing power over citizens to regulate behaviours and influence decision making. For example, recipients are required to enroll each child into an approved early childhood education program from the age of three. Thereafter, the sole parent must actively seek part time employment at a minimum of 20 hours a week. To facilitate the transition into paid employment, parents must also attend interview preparation workshops, skill development seminars, CV writing sessions, readiness for work assessments and other meetings as deemed fit by the Ministry (Work and Income New Zealand, 2018; 2019). These obligations assume that when a child is in formal education, the parent becomes idle labour and needs to engage in the labour markets to actively contribute to society. Therefore, it is expected that such transition will come at no cost (Himmelweit, 2002).

Penalties are invoked, should a recipient fail to meet these obligations without sufficient reasoning. Initially a 50\% reduction in weekly payments can be authorised, and escalated to a 13-week suspension if non-compliance reoccurs (Work and Income New Zealand, 2018). Sufficient reasoning is not defined on application documentation or legislation, indicating this is at the discretion of the administrator. These penalties increase the pressure for recipients to meet policy Obligations.

\subsection{Incentives}

As well as obligations and penalties, the policy applies financial incentives to push beneficiaries into labour market participation. As of the 1st April, 2019 the Sole Parent Benefit was a weekly payment of $\$ 339.69$ NZD (Work and Income New Zealand, 2019). This is menial, equal to only $58.2 \%$ of a full-time minimum wage job. The minimal payment places recipients below the national line of poverty, which is set at $60 \%$ of the median weekly income (see New Zealand Parliament, 2011 and O'Brien, 2016). This approach attempts to make paid 
employment financially attractive, and create an environment where the cost of continued unemployment is unsustainable to draw people into the labour market.

Rational Choice Theory underpins the policy's design and implementation, as evidenced in the policy objectives, obligations, penalties and incentives. Rational Choice theory is fundamental to neoclassical economics, based on the assumption that decisions and behaviours are shaped by a desire to maximise individual positionality in times of resource scarcity (Kabeer, 1994; 2012).Ultimately, the theory anticipates people will respond to income levels and market prices in ways which seek to improve individual well-being (Folbre, 2012). This is a simplistic, reductionist theory, which attempts to constrain motivation complexities into a predictable process, overshadowing the social factors, institutional norms, and cultural expectations that impact decision making and conditions of available work (Agarwal, 1995; Kabeer, 1994).

\section{Methodology}

Harnessing descriptive statistics, this paper provides a statistical overview of recipients of the Sole Parent Benefit, disaggregated by gender. An anonymised data set of recipients was publicly available through the Ministry of Social Development (2017), accounting for the period of September 2012-September 2017. A gendered analysis is then applied, informed by feminist economists Naileer Kabeer, Diane Elson and Nancy Folbre, assessing how market constraints affect New Zealand women's participation in the labour force, and contribute to the counter intuitive policy results.

\subsection{Statistical overview of policy impact and outcomes}

When applying a gendered analysis, statistics show that there are gendered impacts and outcomes of the Sole Parent Benefit, regardless of the obligations, penalties and incentives applied. Because data recorded by the New Zealand Ministry of Social Development is restricted to categories of male and female, this analysis will adopt a gender binary approach, unable to account for gender Diversity.

The New Zealand Sole Parent Benefit is overwhelmingly used by women. As of September $2017,92 \%$ of recipients were female. This trend is a persistent trend, as the percentage of female recipients has remained above 90\% since the establishment of the policy in 2012 (Ministry of Social Development, 2017). With the vast majority of recipients being female, these statistics mirror the social expectation and gendered division of labour that construct mothers and females as the primary care givers in New Zealand society, a social norm which exists in most societies(Chopra \& Sweetman, 2014; Schieder \& Gould, 2016; United Nations Women, 2015).

Sole mothers are remaining on the benefit for longer periods than sole fathers are. After receiving the Sole Parent Benefit for 12 months, each recipient must reapply to evidence a continued need for financial assistance. As this is mandatory, data records are also disaggregated based on receipt of the benefit for more, or less than 12 months. When combining the categories of time and gender, an unequal outcome is evident. The proportion of females remaining on the benefit for more than 12 months is $76 \%$, a rate eight percent higher than the proportion of men (Ministry of Social Development, 2017). These rates of engagement are regardless of the age of the dependents and highlight gendered retention outcomes.

The difference between genders is even greater when assessed in combination with the age of the youngest dependent. Although the legal age of compulsory primary school enrollment is six, it is a social norm for children to start school at the age of five. Because of this, the Ministry of Social Development also maintains data categorised on dependents being over, or under the age of five (Ministry of Social Development, 2017). When the categories of receiving the benefit for more than 12 months and having dependents under the age of five is combined, the proportion of woman reached $41.4 \%$ in 2017 , yet the proportion of men was only $17 \%$ 
(Ministry of Social Development, 2017). These findings reinforce the previous indication that sole mothers remain on the benefit for longer periods than fathers do.

Lastly, the data also shows that the overall rate of recipients has been dropping since 2012, but this too is gendered. Between September 2012 and September 2017, the participation rate for women has dropped by $30.7 \%$, yet, the participation rate has dropped by $40.3 \%$ for men (Ministry of Social Development, 2017). This evidence highlights men are leaving the benefit at a higher rate than women. Data collection, however, is limited. There are no records kept for the rationale behind individuals leaving the benefit and it cannot be assumed that this is solely due to a transition into paid employment. Other factors that could contribute to this trend include entry into a new relationship, the age of dependents no longer meeting the policy criteria, acquisition of assets placing parents over the threshold for government support, or immigration. In order to understand this trend in greater depth, such questions of why people are leaving the benefit is vital.

Table 1.

Summary of gender disaggregated statistics of the New Zealand Sole Parent Benefit

\begin{tabular}{lcc}
\hline Category of analysis & Female & Male \\
\hline $\begin{array}{l}\text { Percentage of total beneficiaries as of September 2017 } \\
\text { disaggregated by gender }\end{array}$ & $92 \%$ & $8 \%$ \\
$\begin{array}{l}\text { Percentage of recipients } \\
\text { receiving payments for over 12 }\end{array}$ & $76.1 \%$ & $68 \%$ \\
$\begin{array}{l}\text { months } \\
\text { Percentage of recipients } \\
\text { receiving payments for over 12 } \\
\text { months with a child under the } \\
\begin{array}{l}\text { age of five years } \\
\text { Reduction in participation rates } \\
\text { between September 2012- }\end{array} \\
\text { September 2017 }\end{array}$ & $41.4 \%$ & $17 \%$ \\
\hline
\end{tabular}

As summarized in table one, these findings clearly evidence a disproportionate impact on women who have both higher and longer rates of engagement. Women and their dependents face greater financial insecurity by enduring a menial wage replacement for extended periods, further affecting the ability to meet basic needs. The policy wording indicates no direct discrimination based on gender, therefore, at face value the disparity of outcomes presents as counter intuitive.

\section{Discussion}

There is no single factor that can explain these gendered impacts and outcomes. Diverse and complex factors influence decisions to provide care, many of which cannot be easily observed (Agarwal, 1995; Folbre, 2009; 2012). Motivators may include internalised moral obligations, personal concern for the care recipient, emotional attachment, fear of potential consequences if care is removed, expectations of future reciprocity, desire for social approval and socialisation into gender roles (Agarwal, 1994; Folbre, 2009; 2012; Himmelweit, 2002). These factors can influence behaviours subconsciously, and they cannot be explained by Rational Choice Theory.

Furthermore, not everything can be given a monetary value. The role of parent-child relationships in development, or the transmission of values and beliefs from parent to child cannot be monetised. Such roles may be valued over economic gains, therefore financial incentives will not necessarily have the intended affects. Caregivers may pursue interests which conflict with individual needs by placing the well-being of the child above their own, all of 
which are behaviours which Rational Choice Theory fails to explain (Folbre, 2009; Himmelweit, 2002).

Motivation is not easily measured, nor is it the only set of circumstances to consider when evaluating the gendered policy outcomes. The objective of the Sole Parent Benefit is to transition sole parents into paid employment, with obligations, penalties and incentive attempting to shape this decision and reinforce the assumed importance of labour market participation. Therefore, a consideration of the structure of the labour market is also vital.

\subsection{Labour markets as gendered institutions}

The labour market is a gendered institution, with gender influencing wages, what roles are accessible and potential for career progression (Elson, 1999; 2017). Individuals and groups make choices and exercise agency every day, however, limits are imposed by structures of constraint (Folbre, 1994; Kabeer, 2012). This paper will now assess the presence of a gender pay gap and horizontal occupational segregation, as well as the motherhood penalty and care constrains to employment opportunities. Each factor evidences gender discrimination in the New Zealand labour market and contributes towards understanding the policy disparities and gendered Outcomes.

\subsection{Gender Pay Gap}

The gender pay gap assess gender pay equity in the labour market. Applied internationally, the gender pay gap calculates differences in hourly pay rates between men and women (Elson, 2017; Lips, 2013; International Labour office, 2018; World Economic Forum, 2018). Evidence of gender pay gaps continue to grow, and has been harnessed as a measure to assess the progress towards achieving Sustainable Development Goal 8.5 which calls for "equal pay for work of equal value" (United Nations Development Program, 2019). However, gender pay gaps have long been defended, with disparities rationalized because of differences in human capital between men and women such as level of education, age and experience (Goblin, 2014). This argument makes invisible persistent gender biases. Even after the proportion of the wage gap explained by differences in human capital has been accounted for, a residual or unexplained proportion remains,evidencing differential treatment and broader gender discrimination in labour markets (Goldin,2014; Lips, 2013; Pacheco, Li \& Cochrane, 2017; Schieder \& Gould, 2016).

While there is no international standard adopted to measure the gap, in New Zealand it is calculated on the median hourly rate for a fixed quantity of paid work (Statistics New Zealand, 2016). Even with the Equal Pay Act (1972) which makes it illegal for employers to refuse the same terms of employment based on sex, or implement gendered pay scales in public and private employment agreements, a gender pay gap of 9.2\% was calculated in 2018 (Statistics New Zealand,2018a). This means, for every dollar a male earns, a female earns 90.8 cents, despite growing labour force participation and women surpassing men in educational attainment (Pacheco, Li \& Cochrane, 2017). The New Zealand gender pay gap has fluctuated around $10.5 \%$ since 2009, with the lowest point recorded at $9.1 \%$ in 2012, and highest in 2016 at $12 \%$ (Statistics New Zealand, 2018a). This indicates there is no clear or stable improvement in conditions of pay for women. This trend is also prevalent internationally with the majority of high-income earning countries stagnating in their progress towards closing the gap (Elson, 2017).

The gender pay gap does not account for the complexity of factors that interact in pay outcomes. For example, part-time verse full-time work, single verse multiple jobs, or selfemployment arrangements all differ in working conditions, level of security, tax obligations and formal benefits such as pension schemes and holiday pay. In New Zealand, women have different work patterns and are more likely than men to engage in part time employment, yet 
the gender pay gap does not account for this difference (Ministry for Women, 2017; Pacheco, Li \& Cochrane, 2017). For a wider perspective on persistent income disparities, a gendered difference in weekly income is also evidence, with females are earning $25 \%$ less than men (Statistics New Zealand, 2018b). This difference is irrespective of hours worked and accounts for all income sources. Both weekly income measures and the gender pay gap evidences women are consistently earn less than men in New Zealand.

\subsection{Horizontal occupational segregation}

Horizontal occupational segregation must also be consulted to assess the gendered nature of labour markets. Horizontal occupational segregation by gender is the clustering of men and women into different employment sectors. This segregation is commonly linked to gendered differences in wages with women predominantly employed in lower paid sectors offering fewer career progression opportunities (see Treiman \& Hartmann, 1981). Although individual agency has a role in this trend, choice is constrained by socialisation into gendered roles, social norms and employer discrimination (Kabeer, 2012; Schieder \& Gould, 2016).Horizontal occupational segregation is evident in New Zealand, with women concentrated in lower paying occupations, including administration, health assistance and social care (Ministry of Women, 2012; Statistics New Zealand, 2018c). These roles are dominated by women and are sectors consistently paid less than jobs monopolised by men, such as heavy machinery operation and driving (Statistics New Zealand, 2018b). New Zealand has taken steps to address such horizontal gendered occupational inequality by harmonizing up. On July the 1st 2017, the Care and Support Worker (Pay Equity) Settlement Act (2017) was enforced, mandating a nationwide increase in pay scales for people employed in the community and personal service sector. While a pay increase of 12\% was notable between 2017 and 2018 labour statistics, the sector remained one of the lowest paid occupations reported on (Statistics New Zealand, 2018b). The settlement, is to be implemented incrementally over a five-year period, therefore, it is too early to assess its full impact (Statistics New Zealand, 2018b).

\subsection{Unpaid care responsibilities and the motherhood penalty}

Care work is a complex term which accounts for a wide range of activities carried out in the context of the family, home and community, which contribute to the physical, emotional, mental and spiritual well-being of others (Chopra \& Sweetman, 2014). This includes domestic work such as meal preparation, cooking, shopping for food and basic needs, vacuuming and laundry, as well as direct care activities such as taking someone to the doctor, assisting with bathing, dressing, and mobility or listening to someone's concerns. When assessing the Sole Parent Benefit, the key eligibility criteria is that an applicant must be the sole carer of a dependent child under the age of 13 , therefore, it can be assumed that all recipients have ongoing care responsibilities.

Internationally, unpaid care work is predominantly the responsibility of women, a social norm evident in New Zealand through the high user rates of women on the Sole Parent Benefit (Cagatay et al, 1995; Chopra \& Sweetman, 2014; Ministry of Social Development, 2017; United Nations Women, 2015). Even in cases where two parents are present and both engage in labour force participation, research shows unpaid care work is typically not redistributed within the home, and women continue to manage the majority of care responsibilities (Elson, 1999; Folbre, 2009; 2012; Kabeer, 2012; Himmelweit, 2002). Questions such as who will assist children with their homework, cook meals, maintain the household chores or stay up during the night when a child is sick must be considered, as these roles and responsibilities do not disappear when a mother enters the paid labour market.

Although unpaid care work has many benefits to both the giver and receiver, such as personal satisfaction and social acceptance, unpaid care responsibilities can have significant 
consequences for women, their labour force participation and earning potential (Folbre, 2012). In New Zealand, research was conducted to measure the existence of a motherhood penalty, defined as a wage disadvantage associated with parental status (Statistics New Zealand \& Ministry of Women, 2017). Drawing data from the June 2016 Household Labour Force Survey, the study analysed the hourly income of fathers compared to mothers and found a pay gap of $17 \%$. This was significantly higher than the pay gap between men and women without children, which was calculated at only five percent. This difference in the gender pay gap between parents and non-parents is therefore considered a motherhood penalty, and the report concluded that gender income disparity is greater when a woman is a mother. This study, however, was a point in time statistical analysis and Therefore, is vulnerable to cohort effects. Furthermore, no longitudinal studies have been conducted in New Zealand to assess any lifetime effects that having children has on labour market participation or earning potential. Yet, this research does reinforce previous findings of Dixon (2000), who stated New Zealand mothers could expect to earn less than childless women of asimilar demographic.

Different methods applied for measuring and defining the motherhood gap means that there is currently no reliable international comparisons available, but studies have indicated that the size of the wage penalty and its duration is impacted by the amount of leave taken by a mother, and the job sector they are employed in (Grimshaw and Rubery, 2015). Many reasons have been researched and theorised in an attempt to build an understanding of the processes which give rise to a motherhood penalty. This includes: labour market interruptions limiting career progression, pursuing part time or flexible jobs to accommodate care responsibilities, social norms and expectations of maternity and care responsibilities institutionalising stereotypes in employer decision making, insufficient state investment in accessible and affordable care alternatives, and perceived lower employment commitment of mothers (Elson, 1999; 2017; Folbre, 2009; 2012; Grimshaw \& Rubery, 2015; Ruth, 2006 as cited in Lips, 2013).All of these factors have a negative impact on employment opportunities, while simultaneously undervaluing the role of unpaid care. Unpaid care work sustains and reproduces the market economy through building human capital, maintaining well-being of waged employers and producing future generations of employers and employees (Cameron \& Gibson-Graham, 2003; Elson, 2017; Himmelweit, 2002). But, persistent labour market constraints obscure the benefits of unpaid care work, concealing women's contributions to society while valorising labour market participation (Folbre, 1994). Further comprehensive and holistic research is required to understand the full complexity behind motherhood penalties and how value is ascribed to unpaid care in New Zealand.

\section{Conclusion}

Even with an equal enforcement of obligations, penalties and incentives upon all recipients to promote labour force participation, the Sole Parent Benefit continues to produce gendered outcomes, leaving women behind. These findings can be considered counter intuitive until a gender analysis is applied. A gendered analysis has made visible the gendered constraints which restrict women's choices and act as a barrier to engagement in formal paid employment. This includes gender pay gaps, horizontal occupational segregation, care responsibilities and motherhood penalties. While these factors do not account for individual differences in motivation, nor individual aspirations, unless the gendered nature of the labour market is addressed, women will continue to face higher rates of engagement on the Sole Parent Benefit. This paper has evidenced that the policy impedes the progress of gender equality in New Zealand. By failing to address the conditions of labour market participation, women and their dependents will continue to experience disproportionate economic disadvantage and financial insecurity. These findings reiterate the importance of applying a gender analysis to policies even in countries considered developed. A gap remains, however, with further research 
required to assess how the Sole Parent Benefit conceptualises the role of unpaid care work in New Zealand.

\section{References}

Agarwal, B. (1995). A field of one's own: Gender and land rights in South Asia. Cambridge, England:Cambridge University Press

Cagatay, N., Elson, D., \& Grown, C. (1995). Introduction. World Development, 23(11), 1827 $-1836$.

Cameron, J., \& Gibson-Graham, J. (2003). Feminising the economy: Metaphors, strategies and politics. Gender, Place and Culture: A Journal of Feminist Geography, 10(2), 145-157.

Care and Support Workers Pay Equity Settlement. No. 24. (2017). Retrieved from http://www.legislation.govt.nz/act/public/2017/0024/28.0/DLM7269110.html

Chopra, D., \& Sweetman, C. (2014). Introduction to gender, development and care. Gender and Development, 22(3), 409-421.

Dixon, S. (2000). Pay inequality between men and women in New Zealand. Occasional Paper 2000/1, New Zealand Department of Labour.

Domestic Violence - Victims Protection Act. No. 21. (2018). http://www.legislation.govt.nz /act/ public/2018/0021/17.0/DLM7054315.html

Elson, D. (2017). Recognise, reduce and redistribute unpaid care work: How to close the gender gap. New Labour Forum, 26(2), $52-61$.

Elson, D. (1999). Labour markets as gendered institutions: Equality, efficiency and empowerment issues. World Development, 27(3), 611 - 627.

Equal Pay Act. No. 118. (1972). Retrieved from http://www.legislation.govt.nz/act/ public/ 1972/0118/latest/DLM407770.html

Folbre, N. (2012). Should women care less? Intrinsic motivation and gender inequality. British journal of Industrial Relations, 50(4), $597-619$.

Folbre, N. (2009). Greed, lust and gender: A history of economic ideas. Oxford, England: Oxford University.

Goldin, C. (2014). A grand gender convergence: Its last chapter. American Economic Review, 104(4), $1091-1119$.

Grimshaw, D., \& Rubery, J. (2015). The motherhood pay gap: a review of the issues, theory and international evidence. Conditions of Work and Employment Series No. 57. Geneva, Switzerland: International Labour Office.

Himmelweit, S. (2011). Making visible the hidden economy: The case for gender-impact analysis of economic policy. Feminist Economics, 8(1), $49-70$.

International Labour Office. (2018). Global wage report 2018/19: What lies behind gender pay gaps? Retrieved from https://www.ilo.org/wcmsp5/groups/public/---dgreports/---dcomm/--publ/documents/publication/wcms_650553.pdf

Kabeer, N. (2012). Women's economic empowerment and inclusive growth: Labour markets and enterprise development. Discussion paper 29/12. Centre for Development Policy \& Research, School of Oriental \& African Studies: University of London. Retrieved from https://www.soas.ac.uk/cdpr/publications/papers/file80432.pdf 
Kabeer, N. (1995). Reversed realities: Gender and hierarchies in development thought. London,England: Verso.

Lips, H. (2012). Acknowledging discrimination as a key to the gender pay gap. Sex Roles, A Journal of Research, 68(3/4), 223-230.

Ministry of Social Development. (2017). Sole Parent Support, youngest child, September 2017. Retrieved from https://www.msd.govt.nz/about-msd-and-our-work/publications resources/ statistics/benefit/archive-2017.html\#SoleParentSupportSPS6

Ministry for Women. (2017). Labour force participation. Retrieved from https://women.govt. nz/work-skills/paid-and-unpaid-work/labour-force-participation

Ministry for Women. (2012). Occupational segregation. Retrieved from https://women.govt .nz/work-skills/paid-and-unpaid-work/occupational-segregation

New Zealand Parliament. (2011). Household incomes, inequality and poverty. Retrieved from https://www.parliament.nz/en/pb/research-papers/document/00PlibCIP181/househo ldinc omes-inequality-and-poverty

O'Brien, M. (2016). Measuring poverty. CPAG brief summary and overview. Child Action Poverty Group. Retrieved from https://www.cpag.org.nz/assets/160701CPAGMeasuring $\% 20$ poverty.pdf

Pacheco, G., Li, C., \& Cochrane, B. (2017). Empirical evidence of the gender pay gap in New Zealand. Ministry for Women. Retrieved from https://women.govt.nz/documents/ empirical-evidence-gender-pay-gap-new-zealand

Schieder, J., \& Gould, E. (2016). "Women's work" and the gender pay gap. How discrimination, societal norms, and other forces affect women's occupational choices - and their pay. Washington, DC: Economic Policy Institute.

Social Security Act 1964, No.136. (2018). Retrieved from http://www.legislation.govt.nz/ act/public/1964/0136/358.0/DLM359107.html

Statistics New Zealand. (2016). Measuring the Gender Pay Gap. Retrieved from https://www.stats.govt.nz/news/gender-pay-gap-is-second-smallest

Statistics New Zealand \& Ministry of Women. (2017). Effect of motherhood on pay methodology and full results. June 2016 quarter. Retrieved from https://www.stats. govt.nz/assets/Reports/Effect-of-motherhood-on-pay-methodology-andfull- results/effectof-motherhood-on-pay-methodology-full-results.pdf

Statistics New Zealand. (2018a). Gender pay gap is second smallest. Retrieved from https:// www.stats.govt.nz/news/gender-pay-gap-is-second-smallest

Statistics New Zealand. (2018b). Labour market statistics (Income) June 2018 quarter. Retrieved from https://www.stats.govt.nz/information-releases/labour-market-statisticsincomejune-2018-quarter

Statistics New Zealand. (2018c). Women in the workforce, 2017. Retrieved from https://www. stats.govt.nz/infographics/women-in-the-workforce-2017

Treiman, D., \& Hartmann, H. (1981). Women, work, and wages: Equal pay for jobs of equal value.Washington, DC: National Academies Press

United Nations Development Program. (2019). Sustainable Development Goal 8 - Promote sustained, inclusive and sustainable economic growth, full and productive. Retrieved from https://sustainabledevelopment.un.org/sdg8 
United Nations Development Program. (2018). Gender Inequality Index (GII). Retrieved from http://hdr.undp.org/en/content/gender-inequality-index-gii

United Nations Women. (2015). Millennium Development Goals: Gender chart. Retrieved from http://www.unwomen.org/-/media/headquarters/attachments/ sections/ library/ publications/2016/mdg-gender-chart-2015-for-web.pdf?la=en\&vs=4956

Work and income New Zealand. (2019). Sole parent support cut out points, current. Retrieved from https://www.workandincome.govt.nz/map/deskfile/main-benefits-cut-outpoints/soleparent-support-cut-out-points-current.html

Work and income New Zealand. (2018). Sole parent support: Obligations and privacy. Retrieved from https://www.workandincome.govt.nz/documents/forms/sole-parent-supp ortobligations-and-privacy-form.pdf

World Economic Forum. (2018). the Global Gender Gap Report 2018. Retrieved from https://www.weforum.org/reports/the-global-gender-gap-report-2018 